\title{
ELECTROPHORETIC PARTITION OF $\beta$-GLOBULINS IN HUMAN SERA BY A NON-IONIC DETERGENT
}

\author{
BY \\ G. A. LLOYD AND G. T. STEWART \\ From the Department of Pathology, Mayday Hospital, Croydon
}

(RECEIVED FOR PUBLICATION JULY 7. 1955)

When analysed by conventional electrophoretic methods with barbiturate buffers, the $\beta$-globulin of human sera usually appears, in filter-paper strips stained for protein, as a single band. In some sera, a second slower-moving band may also appear in the $\beta$ position, but this varies according to the physical conditions employed.

The present paper records the separation of additional components in the $\beta$ position by a nonionic detergent.

\section{Experimental}

Two long chain fatty alcohol-ethylene oxide condensates ("lubrol MOA" and "lubrol W") and an alkylated phenol ethylene oxide condensate (" lissapol $\mathrm{N}$ ") were added to various sera to give final concentrations of $0.4 \% \mathrm{w} / \mathrm{v}$. The treated sera were applied in 0.05 to $0.1 \mathrm{ml}$. volumes to Whatman No. 3 $5 \mathrm{~cm}$. filter-paper strips and analysed electrophoretically in a vertical (Flynn and de Mayo) tank containing $0.05 \mathrm{M}$ barbiturate buffer at $p \mathrm{H} 8.6$ for six and a half or 16 hours at 0.6 or $0.2 \mathrm{~mA} / \mathrm{cm}$. As controls, the untreated sera and detergents alone were similarly analysed. After fixation, the strips were stained for protein (bromophenol blue or azocarmine) and, in some instances, were longitudinally divided to allow one half to be stained also for lipid (Sudan black). The absolute values of the protein fractions were determined by photometric scanning, and the total protein by a Biuret method, using Weichselbaum's reagent.

"Lissapol $\mathrm{N}$ " and the shorter chained "lubrol MOA" had no effect upon the electrophoretic pattern. "Lubrol W," however, provoked the appearance of an intermediate band between the usual $\beta$ - and $\gamma$-globulin bands. No staining reactions were obtained with serum-free paper strips to which the detergents only had been applied.

To avoid the possibility of artefacts, and to facilitatc standardization in further experiments, a second electrophoretic tank was then devised. In this the two buffer channels were divided half-way along the tank into two compartments, the first containing standard buffer and the second the same buffer with $0.2 \%$ (w/v) "lubrol W." Sera analysed electrophoretically in this system again showed similar separation of an intermediate band between the $\beta$ - and $\gamma$-globulins (Fig. 1). In some pathological sera, double or even triple intermediate bands appeared, giving a total of seven fractions (Fig. 2). Half-strips stained with Sudan black showed that the intermediate bands coincided with dense zones of lipid into which practically all the non-particulate mobile serum lipid had been concentrated (Fig. 3). These effects were obtained in plasma as well as in serum. and it was noted that in some instances the fibrinogen band was dispersed in the presence of "lubrol W."

Quantitative estimations by the scanning technique suggested that the intermediate band represented a partition of $\beta$-globulin (Table) though, in some sera. subtractions from the $\gamma$ or $\alpha_{2}$ fractions appeared to contribute. The contribution from $\alpha_{2}$ globulin obviously depended upon the proportion of lipid present as $\alpha$-lipoprotein. The influence of "lubrol W" upon the lipid-free protein fractions was studied by electrophoresing a $5 \%$ mixture of purified albumin and $\gamma$-globulin. Although the mixtures were found to be not quite pure electrophoretically, no partitioning effect on these lipid-free proteins was observed.

In a further series of experiments, sera were extracted with various fat solvents. It was found that extraction with ether at $-20^{\circ} \mathrm{C}$. for two hours or more removed the Sudan-staining lipid bands produced by "lubrol W," and reduced the intensity of the intermediate protein bands. In all the sera tested the intermediate protein bands were found to correspond to concentrated lipid.

The above effects were obtained only with "lubrol W." The other non-ionic detergents tested were inert under these experimental conditions. When an anionic sulphonated detergent ("dispersol $T$ ") was used, the electrophoretic mobility of the albumin and $\alpha$ - $\beta$-globulins was increased, but no additional intermediate bands appeared. In contrast to this, and in addition to its partitioning property, the non-ionic "lubrol $\mathrm{W}$ " diminished the mobility of the fractions and caused a corresponding increase in the optical density of the stained bands. 


\section{Discussion}

The $\beta$-globulins of human sera are known to be a complex mixture of " pure" proteins and lipoproteins. Solubilization of the lipoid component of the complex could be expected to alter the mobility and apparent proportions of the associated globulins. From their formulae and other properties, long-chain fatty alcohols may well effect such solubilization, and enhance the separa- significant factor in separation since an aromatic, water-soluble but non-ionic detergent ("lissapol $\mathrm{N}$ ") failed to produce the effect. The use of an ionized (anionic) detergent ("dispersol $\mathrm{T}$ "disodium salt of methyl naphthalene sulphonate) increased mobility without differentiating the $\beta$ complex.

A second, slower moving $\beta$-component can also be separated by using borate buffer, according to

(a)

(b)

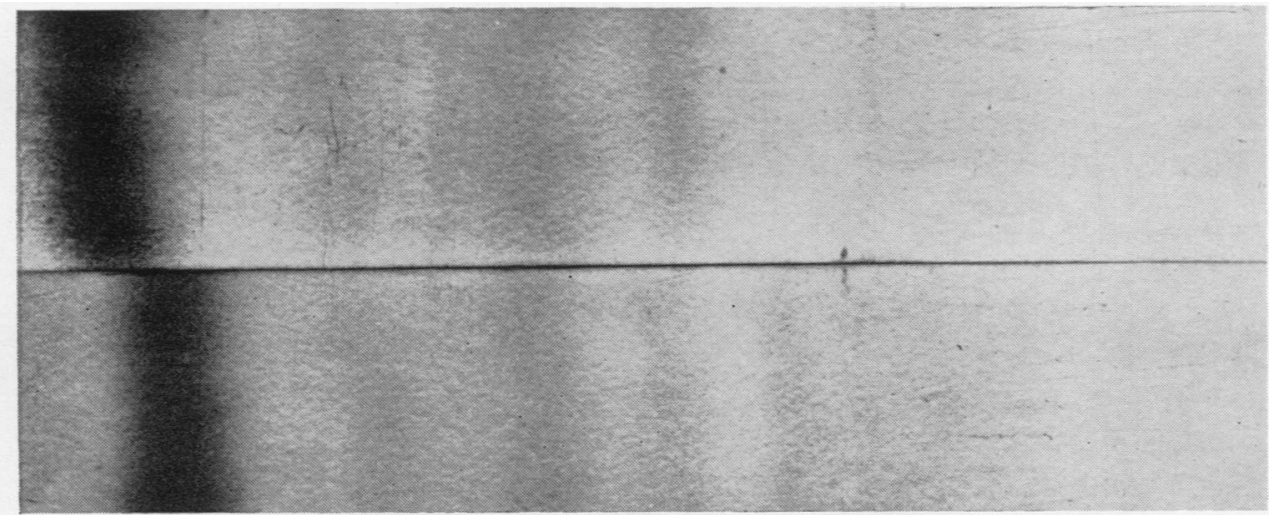

FIG. 1 (a). - Normal serum (barbitone only). (b) Normal serum (barbitone with " lubrol W").

(a)

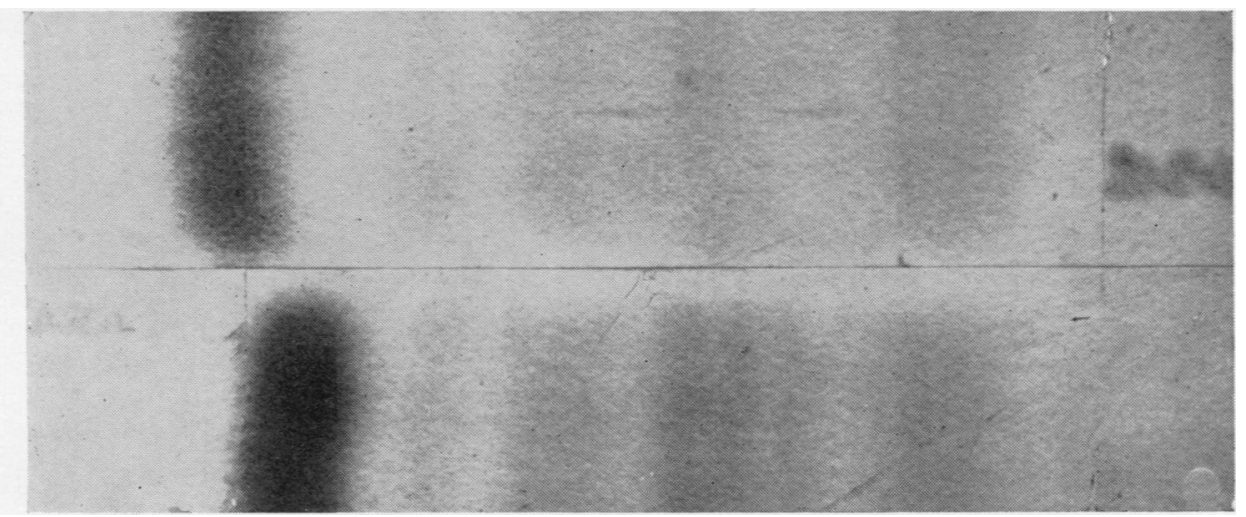

Fig. 2 (a).-Abnormal serum (barbitone only). (b) Abnormal serum (barbitone with "lubrol W").

FIGs. 1 AND 2.-Effect of " lubrol $W$ " on protein fractions of serum as shown by paper electrophoresis of $0.07 \mathrm{ml}$. volumes.

tion of a second $\beta$ - (or other intermediate) globulin. The fact that "lubrol $W$ " is active, whereas "lubrol MOA" with a similar, though shorter, fatty chain, is inert, suggests that effective separation depends also on high solubility of the detergent itself in the aqueous phase of the serum. The position of the intermediate band in the segment stainable by Sudan black, and its disappearance in ether-extracted sera, indicate that the separated component is largely lipid in nature. Surface activity in itself does not appear to be a
Consden and Powell (1955). These workers attribute this effect to the formation of complexes between borate ions and $\alpha$-glycol groups in the lipoid components of the $\beta$-globulins (Martin and Franglen, 1954).

Estimates of the quantities and exact origins of the intermediate protein fractions are rendered difficult by the slight alterations which "lubrol W" (in common with many other substances) cause in mobility and optical density of the stable fractions, as well as by other well-known limitations of 
ABSOLUTE VALUES OF SERUM PROTEIN FRACTIONS AFTER ELECTROPHORESIS IN BARBITONE AND BARBITONE - "LUBROL W" BUFFERS

\begin{tabular}{|c|c|c|c|c|c|c|c|c|c|c|c|c|c|c|}
\hline \multirow{2}{*}{$\begin{array}{c}\text { Serum } \\
\text { No. }\end{array}$} & \multirow{2}{*}{ Type } & \multirow{2}{*}{$\begin{array}{c}\text { Total } \\
\text { Protein } \\
(\mathrm{g} . \%)\end{array}$} & \multicolumn{5}{|c|}{ Fractions (g.\%) in Barbitone Buffer } & \multicolumn{7}{|c|}{ Fractions (g. $\%$ ) in Barbitone-“ Lubrol W" Buffer } \\
\hline & & & Albumin! & $a 1$ & $a 2$ & $\beta$ & $\because$ & Albumin & $a 1$ & $a 2$ & $\beta(1)$ & $(2)$ & (3) & (1) $\gamma(2)$ \\
\hline $\begin{array}{l}1 \\
2 \\
3 \\
4\end{array}$ & $\begin{array}{l}\text { Total protein low } \\
\text { Globulin total within } \\
\text { normal limits }\end{array}$ & $\begin{array}{l}5 \cdot 40 \\
5.40 \\
6 \cdot 20 \\
6 \cdot 30\end{array}$ & $\begin{array}{l}2.55 \\
2.00 \\
3.30 \\
3.05\end{array}$ & $\begin{array}{l}0.48 \\
0.51 \\
0.41 \\
0.28\end{array}$ & $\begin{array}{l}0.73 \\
1.03 \\
0.89 \\
0.35\end{array}$ & $\begin{array}{ll}0 & 82 \\
0 & 83 \\
0.50 \\
0.67\end{array}$ & $\begin{array}{l}082 \\
1.03 \\
1.10 \\
1.95\end{array}$ & $\begin{array}{l}2 \cdot 50 \\
2 \cdot 34 \\
2.92 \\
2 \cdot 84\end{array}$ & $\begin{array}{ll}0 & 33 \\
0 & 26 \\
0 & 37 \\
0 & 20\end{array}$ & $\begin{array}{l}0.77 \\
1.00 \\
0.71 \\
0.33\end{array}$ & $\begin{array}{l}0.59 \\
0.52 \\
0.38 \\
0.62\end{array}$ & $\begin{array}{l}0.40 \\
0.38 \\
0.55 \\
0.53\end{array}$ & $\begin{array}{l}0.26 \\
0.26 \\
0.25 \\
\end{array}$ & $\begin{array}{l}0.55 \\
0.64 \\
1.01 \\
1.78\end{array}$ \\
\hline $\begin{array}{l}5 \\
6\end{array}$ & $\begin{array}{l}\text { Total protein low } \\
\text { Globulin high }\end{array}$ & $\begin{array}{l}5 \cdot 40 \\
6 \cdot 00\end{array}$ & $\begin{array}{l}1 \cdot 64 \\
1 \cdot 98\end{array}$ & $\begin{array}{l}0 \cdot 45 \\
0 \cdot 39\end{array}$ & $\begin{array}{l}2 \cdot 24 \\
0 \cdot 82\end{array}$ & $\begin{array}{l}0 \cdot 53 \\
0.91\end{array}$ & $\begin{array}{l}0.54 \\
1.70\end{array}$ & $\begin{array}{l}1 \cdot 62 \\
1 \cdot 83\end{array}$ & $\begin{array}{l}0.40 \\
0.39\end{array}$ & $\begin{array}{l}2 \cdot 16 \\
072\end{array}$ & $\begin{array}{l}0.23 \\
0.72\end{array}$ & $\begin{array}{l}0.46 \\
0.62\end{array}$ & - & $\begin{array}{l}0.53 \\
1.72\end{array}$ \\
\hline $\begin{array}{r}7 \\
8 \\
9 \\
10\end{array}$ & $\begin{array}{l}\text { Total protein within } \\
\text { normal limits }\end{array}$ & $\begin{array}{l}7 \cdot 40 \\
6 \cdot 40 \\
6 \cdot 70 \\
7 \cdot 10\end{array}$ & $\begin{array}{l}4 \cdot 25 \\
3 \cdot 91 \\
3 \cdot 23 \\
3 \cdot 96\end{array}$ & $\begin{array}{l}0.22 \\
0.18 \\
0.20 \\
0.62\end{array}$ & $\begin{array}{l}0.82 \\
0.71 \\
0.61 \\
0.76\end{array}$ & $\begin{array}{l}0.95 \\
0.98 \\
1.02 \\
0.92\end{array}$ & $\begin{array}{l}1.16 \\
062 \\
1.64 \\
0.84\end{array}$ & $\begin{array}{l}3 \cdot 95 \\
4 \cdot 24 \\
3 \cdot 41 \\
4 \cdot 10\end{array}$ & $\begin{array}{l}0.27 \\
0.18 \\
0.16 \\
0.55\end{array}$ & $\begin{array}{l}0.82 \\
0.39 \\
0.64 \\
0.82\end{array}$ & $\begin{array}{l}1.00 \\
0.39 \\
0.89 \\
0.76\end{array}$ & $\begin{array}{c}0.36 \\
0.36 \\
\overline{0.18}\end{array}$ & $\begin{array}{c}-\overline{0.23} \\
0.44 \\
-\end{array}$ & $\begin{array}{l}1.00 \\
0.61 \\
1.16 \\
0.79\end{array}$ \\
\hline $\begin{array}{l}11 \\
12 \\
\end{array}$ & $\left.\begin{array}{l}\text { Total protein and globulin } \\
\text { high }\end{array}\right\}$ & $\begin{array}{r}8 \cdot 20 \\
12 \cdot 00 \\
\end{array}$ & $\begin{array}{l}1 \cdot 84 \\
4 \cdot 03 \\
\end{array}$ & $\begin{array}{l}0.43 \\
0.54 \\
\end{array}$ & $\begin{array}{l}1 \cdot 06 \\
1 \cdot 20\end{array}$ & $\begin{array}{l}1 \cdot 44 \\
1 \cdot 16\end{array}$ & $\begin{array}{l}3 \cdot 43 \\
5 \cdot 07\end{array}$ & $\begin{array}{l}1 \cdot 92 \\
4 \cdot 00\end{array}$ & $\begin{array}{l}0.40 \\
0.55\end{array}$ & $\begin{array}{l}1.02 \\
1.21\end{array}$ & $\begin{array}{l}0.76 \\
0.70\end{array}$ & $\begin{array}{l}0.35 \\
0.35 \\
\end{array}$ & - & $\begin{array}{c}1.322 .43 \\
15.19\end{array}$ \\
\hline
\end{tabular}

(a)

(b)

(c)

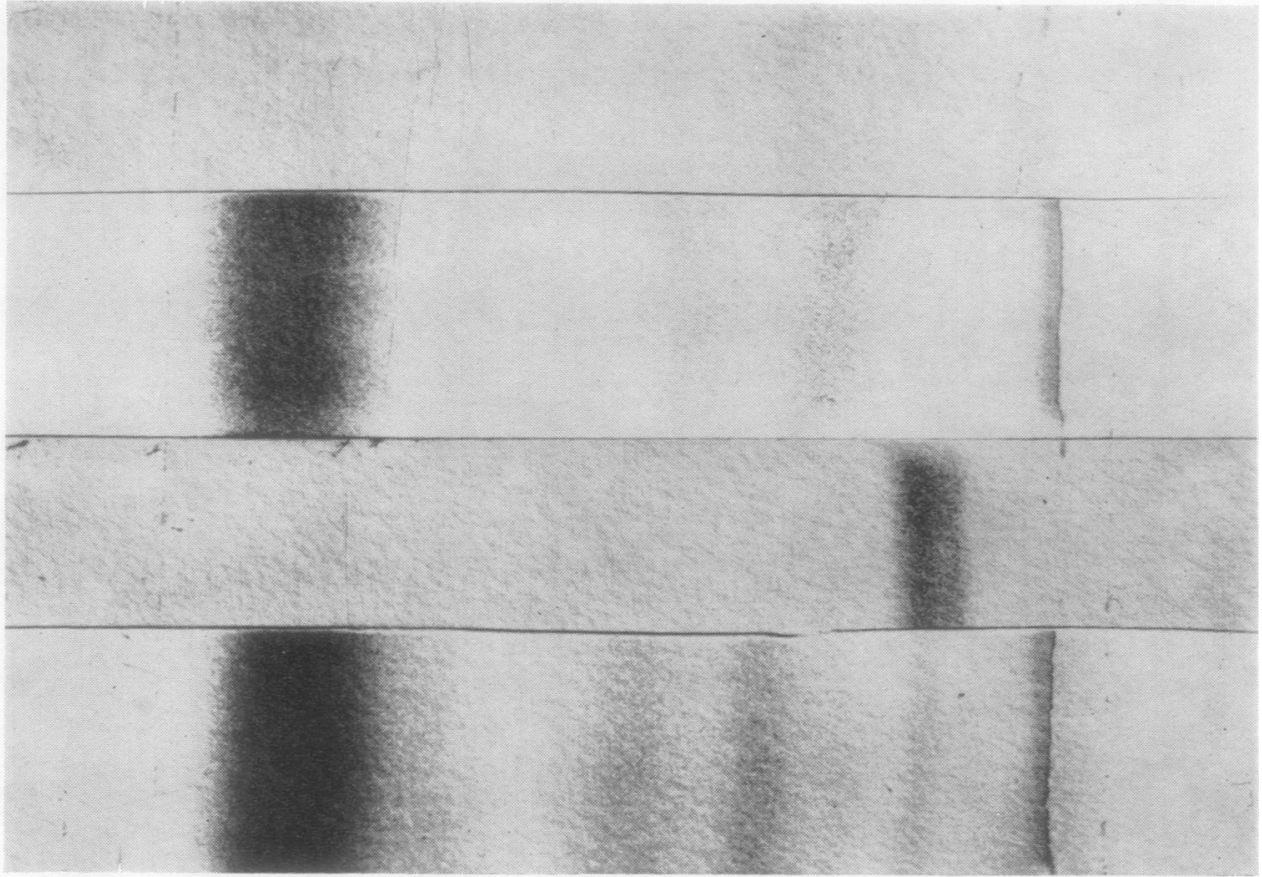

FIG. 3.-Effect of "lubrol $\mathrm{W}$ " on protein and lipid fractions of plasma as shown by paper electrophoresis of $007 \mathrm{ml}$ volumes. (a) Barbitone buffer only (lipid). (b) Barbitone buffer only (protein). (c) Barbitone buffer with "lubrol W" (lipid). (d) Barbitone buffer with "lubrol W" (protein).

paper-strip electrophoresis. It seems likely, however, that $\beta$-globulin is the main source, with occasional and variable increments from the $\alpha$-globulins depending upon the concentration and distribution of the associated lipids which are transferable to the new position.

\section{Summary}

The addition of a non-ionic fatty alcohol ("lubrol W") to barbiturate buffer causes separation of one or more intermediate protein bands between the $\beta$ - and $\gamma$-globulins of sera analysed electrophoretically. The bulk of the $\alpha$ - and $\beta$ - lipid is also moved to a corresponding position.

This effect appears to be due to a specific interaction of the long polyethylene chain of the detergent with the lipid components of the $\alpha$ - and $\beta$ globulin complexes in normal and abnormal sera.

Grateful acknowledgment is made to Miss $M$. Grodzinski and Mr. W. Archibald for their assistance in these experiments, and to Imperial Chemical Industries Ltd. for supplies of various types of detergents and advice on their properties.

\section{REFERENCES}

Consden, R., and Powell, M. N. (1955). Journal of Clinical Pathology, 8,150 .

Martin, N. H., and Franglen, G. T. (1954). Ibi 1., 787. 